\title{
Iterability and Différance: Re-tracing the Context of the Text
}

Roland Theuas S. Pada

\section{"Signature Event Context" and Speech Act Theory}

$\mathrm{I}$ $\mathrm{n}$ the conveyance of meaning, communication is thought of as the exchange of information between two or more individuals, in which meaning is appropriated through a system of communication that conveys the intention of both parties. Communication in its basic sense could be as simple as a gesture or a series of bodily movements that are meaningful, not only to the manifestator, but also to the recipients. In order for this to happen, such gestures or manifestations of intentions to "communicate" must in themselves be always already given to both the manifestator and the recipients. In other words convention makes it possible for communication to occur, for in the manifestation of a "sign" or "meaning" towards an other, the manifestator makes use of a system that allows an other to decipher its intention to "communicate," for in its failure to make a gesture or a manifestation to be understandable or mentally "legible," the whole process of communication defeats its own purpose. Thus, a bank robber, for example, will not drop down his pants to signal his surrender when cornered by the police,${ }^{1}$ rather he will raise his arms up to the sky to "show" the absence of resistance in his countenance. But what made it a convention or a "tradition" for people to raise their hands up as a signifier for "surrender" instead of dropping down one's pants?

In the advent of communication, Derrida finds that meaning through signification carries with it the possibility of mis-communication ${ }^{2}$ in which the intended meaning behind the text becomes undecidable and inevitably polysemic in its transference. In a short, yet fecund essay "Signature Event Context," Derrida tackles the problem of communication and the supposed claim of the classical notion of writing's conception of virtual permanence within the text. ${ }^{3}$ The classical notion of writing claims that writing as a medium or a species of communication ${ }^{4}$ implies that the transference of

\footnotetext{
${ }^{1}$ Perhaps his underwear was white, signaling his surrender to the police.

2 Cf. Jacques Derrida, Limited Inc., trans. by S. Weber and J. Mehlman (Evanston Illinois: Northwestern University Press, 1988), 156-157 [note 9 for Limited Inc. a b c].

3 Derrida, "Signature Event Context," in Limited Inc., 9. See also Jacques Derrida, Margins of Philosophy, trans. by A. Bass (Chicago, University of Chicago Press, 1982), 314.

${ }^{4}$ Ibid., 6.
} 
meaning is conducted in a homogenous fashion. In the absence, ${ }^{5}$ of the author who has abandoned the fleeting singular instance of inscription, the text, according to the classical notion of writing, must be able to transfer meaning within the interplay of the text itself, for if it fails to do so, writing would cease to become useful in its intention to transfer meaning.

Derrida takes advantage of this context as a way of further elaborating his notion of polysemia and dissemination, and from this he deconstructs J.L. Austin's Speech Act Theory found in the latter's work How To Do Things With $W_{\text {ords }}{ }^{6}$ in order to demonstrate that writing (or representation in a general context) carries with it the constant possibility of polysemia through dissemination. Derrida claims that in spite of Austin's new classification of the notion of communication, Austin's "speech act theory" shares the same problems that have plagued the classical notion of writing. Like Derrida's criticism of the metaphysics of presence, Austin shares the same concern of moving away from the strict systematization of language as a fixed structure that is supposedly hierarchical in a sense that language becomes an unalterable domain of meaning in which its users simply "borrowed" or "used" such always already accessible tool. ${ }^{8}$ Austin explores an apparently neglected, though obvious, means of communication that goes beyond the traditional expression of truth or falsity as an adequation. It is in Austin's speech act theory that one finds words as a manifestation of an effect rather than the conveyance of truth or falsity in the traditional sense of prepositional logic.

Austin, in this regard, explores the nature of locution as a performative, in which for him, most grammarians have failed to acknowledge and only

5 To note, Derrida pays a significant attention on this term through this essay. Derrida inherits this through his reading of Condillac's in which the notion of the trace is found to be congruent with Derrida's earlier discussion on Of Grammatology.

6 Cf. J.L. Austin, How To Do Things With Words, ed. by J.O. Urmson and Marina Sbisà (London, Oxford University Press, 1975).

${ }^{7}$ Derrida emphasizes that by moving away from the traditional notion of locution or proposition making, Austin is able to explore a different manifestation of representations not as a conveyance of truth or falsity, but rather on the production of an effect or impulse towards an other: “. . .This category of communication is relatively new. Austin's notions of illocution and perlocution do not designate the transference or passage of a thought-content, but, in some way the communication of an original movement, an operation and the production of an effect." Derrida, Limited Inc., 13.

8 Arguing in the same vein as Derrida's deconstruction would, Austin thinks that the dogmatic idealization of statements as "verifiable" from its origin has created a variety of nonsensical statements that merely produced an unending chain of intellectual masturbations. $\mathrm{He}$ finds the fault to be existing within those who were supposed to be responsible for overcoming such fault: "But now in recent years, many things which would once have been accepted without question as 'statements' by both philosophers and grammarians have been scrutinized with new care. This scrutiny arose somewhat in-directly - at least in philosophy. First came the view, not always formulated without unfortunate dogmatism, that a statement (of fact) ought to be 'verifiable,' and this led to the view that many 'statements' are only what may be called pseudostatements. First and most obviously, many 'statements' were shown to be, as Kant perhaps first argued systematically, strictly nonsense, despite an unexceptionable grammatical form: and the continual discovery of fresh types of nonsense, unsystematic though their classification and mysterious though their explanation is too often allowed to remain, has done on the whole nothing but good." Austin, How to Do Things With Words, 2. 


\section{ITERABILITY AND DIFFÉRANCE}

incidentally discussed by philosophers. ${ }^{9}$ Performatives are statements that do not convey the actual transference of "existing" and verifiable entities or beings by a speaker or an author, rather, performatives are considered to be futural claims of presence or, simply put, promises ${ }^{10}$ intended to bring a particular effect towards its recipient. Austin notes the two simple description of what a performative is:

A. They do not describe or 'report' or constate anything at all, are not 'true or false'; and

The uttering of the sentence is, or is a part of, the doing of an action, which again would not normally be described as, or 'just' saying something. ${ }^{11}$

Austin uses a variety of examples to demonstrate the activity that takes place in the utterance of a performative, one of which involves the utterance of a bet in which the futural activity of paying the winner of the bet becomes the performance of the statement. ${ }^{12}$ For example, one may utter "I bet my entire collection of vintage Gibson Les Pauls that you would not be able to successfully defend your thesis this March," the utterance here does not actually take place, not until the condition of the bet is met. In other words, the presence of the act of surrendering or not surrendering the set of vintage guitars is only acted upon the fulfillment or non-fulfillment of the condition, which is to fail or not to fail the thesis defense on March. The statement is of course not something that is signified from an empirical or extra-mental reality; rather it is a statement that promises presence through the effect of a future performance.

To note, Derrida finds Austin's thoughts to be an interesting divergence from logocentrism on the account that communication no longer focuses on the referentiality of the object of what is communicated, but rather on the effect of what is being uttered. However, in the course of Derrida's essay, Derrida still finds Austin guilty of committing the very same logocentric tendencies that Austin has been trying or at least, seems to be avoiding. Logocentrism, as far as Derrida is concerned in the context of presence and representation, is the belief that the signified remains fixed and constant so that in its referral via a signifier, the text remains the same in repetition. In Austin, this problem manifests itself in his belief that a 'grand' or a 'total context' determines the success of performatives. This context determines the felicity or the infelicity of a particular speech act. Felicity occurs as the fulfillment of the promise or the performance of the performatives, in other words, in its claims of a futural possibility of presence (Jouissance), felicity happens as a result of making something present within the consciousness of its recipient, with the hopes of

\footnotetext{
${ }^{9}$ Ibid., 4.

${ }^{10}$ Ibid., 6-7.

${ }^{11}$ Ibid., 5.

12 Ibid., 7.
} 
effecting an intended effect on its receiver. The fulfillment of such, for Austin is fulfilled within a specific circumstance or context that determines the possibility of performance. ${ }^{13}$ The assumption for this however, is that the individuals involved in the act of uttering a performative appropriates a fixed intention or the value of what is being communicated. Derrida notes this problem in Austin:

And yet - such at least is what I should like to attempt to indicate now - all the difficulties encountered by Austin in an analysis which is patient, open, aporetical, in constant transformation, often more fruitful in the acknowledgment of its impasses than in its positions, strike me as having a common root. Austin has not taken account of what - in the structure of locution (thus before any illocutory or perlocutory determined) - already entails that system of predicates I call graphematic in general and consequently blurs [brouille] all the oppositions which follow, oppositions whose pertinence, purity and rigor Austin has unsuccessfully attempted to establish. ${ }^{14}$

For Derrida, Austin seems to be unable to establish the necessary distinctions in his speech act theory because he fails to establish the conditional possibilities of appropriation within utterances or texts. In a simpler way, Derrida thinks that Austin's version of the speech act theory is riddled with problems because it does not take into account the fact that performatives are still utterances that require referentiality, not only to empirical entities, but rather also to extramental phenomena at work in the intention of a conscious subject. Moreover, Derrida finds that Austin is trying to isolate utterances that do not conform to an overarching context or convention in which statements mean something with precision. ${ }^{15}$ Austin aptly calls these phenomena as instances of the parasiticall ${ }^{16}$ use of language, in which the use of words and utterances are faced with the risk of falling prey to.

The focus of Derrida's criticism of Austin is based on the assertion that the repeatability of a text or an utterance is always situated with the possibility of misappropriation as its constant structure. I think that the intention of Derrida is not entirely to disrupt or efface Austin's speech act theory, but rather to improve it by adding to it the possibility of polysemia and

13 "The uttering of the words is, indeed, usually a, or even the, leading incident in the performance of the act, the performance of which is also the object of the utterance, but is far from being usually, even if it is ever, the sole thing necessary if the act is to be deemed to have been performed. Speaking generally, it is always necessary that the circumstances in which the words are uttered should be in some way, or ways, appropriate, and it is very commonly necessary that either the speaker himself or other persons should also perform certain other actions, whether 'physical' or 'mental' actions or even acts of uttering further words." Ibid., 8.

${ }^{14}$ Derrida, Limited Inc., 14.

15 Ibid., 16.

16 Austin, How to Do Things With Words, 22. 


\section{ITERABILITY AND DIFFÉRANCE}

dissemination in the course of determining felicities and infelicities in an utterance. However, in this attempt, Derrida meets some resistance from one of Austin's students, John Searle. With the exclusion of the complete copy of Searle's reply to Derrida, ${ }^{17}$ the entire debate is documented, albeit favoring Derrida's side, in Limited Inc. Searle argues that in the deconstruction of Austin speech act theory, Derrida seems to have made a mis ${ }^{18}$-interpretation of Austin's intention of segregating the parasitic use of language as a metaphysical exclusion..$^{19}$ Derrida is said to be rendering an illegitimate or an unrecognizable version of the speech act theory because he did not perceive Austin's intention of establishing a parasitic discourse as a mere "relation of logical dependence" 20 and not as a derogatory remark towards the dysfunction of language. Searle further argues that Derrida's notion of writing as a model of iterability (repetition), fails to establish graphematics ${ }^{21}$ due to its logical dependence towards writing as "a contingent fact about the history of human languages." 22 Searle states that since both "speakers and hearers" are both masters of the languages that they speak in a particular context, the problem of absence in writing is not problematical in the iterability of language because the rules of language in which they have acquired mastery from "allow[s] for the repeated application of the same rule."23

The debate, however, could be concluded as a draw, for one may argue on both sides while retaining the same results of Derrida and Searle's arguments. In Kevin Halion's Dissertation, Deconstruction and Speech Act Theory: A Defense of the Distinction Between Normal and Parasitic Speech Acts, Derrida and Searle's positions are resolved through the contextualization of their works. ${ }^{24}$ Halion's reading of Derrida and Searle makes it apparent that their positions are defensible with each other's notion of the speech act theory and its underlying difficulties of iteration. ${ }^{25}$ Whereas Derrida would show that the problem of iteration carries with it the problem of the fluctuation of language, Searle shows that the possibility in of the occurrence of this problem is only upon the context of the fluctuations of space and time. It is not to say that Derrida is against the impossibility of meaning, but rather on the absolute congruence of its transference from the utterer to its hearer. It is in this regard

\footnotetext{
${ }^{17}$ John Searle, "Reiterating the Differences: A Reply to Derrida," in Glyph, 1 (1997), 198-208.

18 In deference to Derrida, I am pre-empting the usage of the word "mis" as an emphasis for later discussions that would best explain this unconventional divergence.

${ }^{19}$ Searle, Reiterating the Differences: A Reply to Derrida, 205.

${ }^{20}$ Ibid.

21 The system of writing as a mode or species of communication.

22 Ibid., 207.

${ }^{23}$ Ibid., 208.

24 Kevin Halion, "Deconstruction and Speech Act Theory: A Defense of the Distinction Between Normal and Parasitical Speech Acts," in <http://www.kkhec.ac.ir/Linguistics $\% 20$ articles $\% 20$ index/Deconstruction $\% 20$ and $\% 20$ Speech $\% 20$ Act $\% 20$ Theory\%20-\%20Austin,\%20Derrida,\%20Sear.htm>, Accessed on December 18, 2009.

25 Ibid.
} 
that Halion was able to prove that the distinction between the normal and parasitical usage of language could be resolved within Searle and Derrida's texts. ${ }^{26}$ Ironically, the debate is prolonged only because Derrida and Searle have mis-contextualized the intentions of their critique of Austin.

Using this fecund debate as a starting point, I intend to elevate Derrida's notion of logocentrism, not merely as a metaphysical etiolation ${ }^{27}$ of presence, but as an explanation of how it is able to establish the congruency of the representation of a singularity found in the intention of an author and that of its interlocutor. The ensuing discussion will revolve around the rubrics of the speech act theory (from Austin and Searle) as a supplement to Derrida's deconstruction. I will also demonstrate the possibility of logocentrism as an imperative of communication without denying Derrida's critique of the metaphysics of presence. In other words, I will show that Derrida's deconstruction of logocentrism utilizes logocentrism itself as a context for its operation in the reading and writing of a text.

\section{The Parasite of Logos: Différance}

The dispute or the so-called "debate" that has occurred and transpired between Derrida and Searle involves the problem of iterability of a speech act, particularly within the process of the text's repetition within the consciousness of the other. Central to this debate is Austin's notion of iterability as the fulfillment of speech act, which in turn creates felicities and infelicities ${ }^{28}$ as an effect of its utterance. ${ }^{29}$ Austin, in discussing the axioms involved in the occurrence of felicities and infelicities, spoke of the possibility in which they are fulfilled and not fulfilled in the context of parasitism as an utterance that makes use of non-conventional language in special circumstances:

. . a performative utterance will, for example, be in a peculiar way hollow or void if said by an actor on the stage, or if introduced in a poem, or spoken in a soliloquy. This applies in a similar manner to any and utterance - a seachange in special circumstances. Language in such circumstances is in special ways - intelligibly - used not seriously, but in ways parasitic upon its normal use - ways which fall under the doctrine of the etiolations [non-

\footnotetext{
${ }^{26} \mathrm{Ibid}$.

${ }^{27}$ Etiolation implies the disfunction of a plant that has lost its vigor due to the lack of sunlight or nutrients. Austin is credited for the use of this term.

${ }^{28}$ It is interesting to note that in Austin, felicities and infelicities resembles Derrida's usage of the word Jouissance, whereas a felicity would incur the fulfillment of a "presence" in an other's consciousness, while its counterpart presents the inability of the other to make a speech act present in its own consciousness, thus producing the effect of a failed or an unhappy nonpresence.

${ }^{29}$ Austin, How to Do Things With Words, 14-15.
} 


\section{ITERABILITY AND DIFFÉRANCE}

structural, unconventional, or unnatural of language. All this we are excluding from consideration. ${ }^{30}$

Austin considers this non-conventional use of language as parasitical in so far as it is prone to create misfires ${ }^{31}$ in the fulfillment of performatives, and would then be subjected to the recurrence of further infelicities. One may take for example, the idea of using poetry to settle cases in court, whereas the language itself may present the problem of accuracy and convention, to which most courts would find confusing and even unintelligible. Let us say hypothetically, that a lawyer-poet, tries to defend his client, a male proctologist, from the accusation of raping another male client under his diagnosis:

To the other man's abyss

My client tried to see

In his disraughtful spelunking

Only did he see

The impetus of breaching

This conatus that is not open to you and me

Chamber maiden! Uttered he

Please help this man from struggling!

As I insert this Odysseus inside he

Of the one who has

A mysterious inhabitant in his ass ${ }^{32}$

As opposed to the use of "normal" or default language, this defense leaves plenty for the imagination to the point that it obscures the meaning or the intention behind the "statement." Thus, instead of performing its intended goal, the lawyer-poet obfuscates the meaning of his utterance to the point of inviting infelicities to infiltrate his statement. Though the intention of this imaginary lawyer-poet demonstrates the problem that occurs within an utterance, which Derrida aims to shed light on through a deconstructive reading of Austin.

When Austin makes the distinction between parasitical and nonparasitical as a distinction between the normal uses of language and the etiolated uses of language, he already makes a claim that there is a natural structure that governs all forms of locutions, and it is in this claim that Derrida bases his critique. Derrida playfully considers Austin's distinction to be a possible risk in which language is subjected as a constant possibility. ${ }^{33}$ In Dissemination, he shows that the re-presentation of presence becomes entangled with the subjectivity of

\footnotetext{
${ }^{30}$ Ibid., 22 [My interpolation].

${ }^{31}$ Ibid., 25.

32 This poem is my own composition.

${ }^{33}$ Derrida, Limited Inc., 17.
} 
an author that is absent from the work. ${ }^{34}$ Austin's attempt to mend this problem is noted by Derrida with some admiration, 35 for Austin's gesture of acknowledging the problems that haunts his analysis of speech act theory already opens a fruitful, if not a lengthy, possibility of investigating the functions and limitations of language as graphematics. ${ }^{36}$ The risks however, must be explicitly stated as a problem of congruency rather than that of identity. For in order to speak of language as a system that signifies an exact signified, one must first prove that all utterances are understood exactly as its speaker originally intended it to be. For Stanley Fish, Austin's strategy is quite similar to Derrida's double gesture, for in stating an axiom, Austin is quick enough to set the margins of that axiom by reconceiving the very axiom that he has stated from the beginning of his previous lecture, ${ }^{37}$ and it is in this gesture that Austin is able to tease out, much like deconstruction, the limitations in which his axioms are applied.

With the exception of Austin's isolation of parasitical speech acts as an etiolation of language, Derrida's position on the repeatability of utterances or texts is very much compatible with Austin's notion of writing. For Derrida, writing is the radical absence of presence, in which the origin or the source of the text is put into question with regards to its similarities and differences from the possible and extractable 'meanings' in the structure of the text. In Ferdinand de Saussure's distinction between speech and writing, Derrida is able to point out that writing and speech bear similar absences, for despite the immediacy of speech in transferring meaning towards its receiver, the receiver is still set back with the problem of decoding the intention of its speaker. Thus, in this sense, speech, just like writing, faces the problem of overcoming the absence of presence, in the sense that presence becomes simulated and at the same time dissimulated by the obviousness of the signified's not-being-there in the text. In this radical absence of presence, language (speech and writing) replaces presence as a supplement for its inability to take scene as it was in the consciousness of an other. One may say that language is similar to the news that is read in the papers or seen in the television, one does not need to be there to actually know what took place in a particular event. Language similarly functions in this way, it does not really need to point or to signify an actual presence in order for its intended effect to manifest; in fact, it is the very nature

34 This allusion is rendered fictionally in his reading of Mallarme's mimodrama, wherein the repetition or the miming of the scene becomes altered according to the mime's understanding of the scene. Cf. Jacques Derrida, Dissemination, trans. by B. Johnson (Chicago: University of Chicago Press, 1981).

35 “. . . all the difficulties encountered by Austin in an analysis which is patient, open, aporetical, in constant transformation, often more fruitful in the acknowledgment of its impasses than in its positions, strike me as having a common root." Derrida, Limited Inc., 14

${ }^{36}$ Graphematics refers to a system of representation or signfication, Derrida would refer to this as Grammatology in his similarly entitled work.

${ }^{37}$ Cf. Stanley E. Fish, With the Compliments of the Author: Reflections on Austin and Derrida, Jacques Derrida, vol. 2, ed. by Christopher Norris and David Roden (London: SAGE Publications, Ltd., 2003), 205-233. See Also, Critical Inquiry, 8 (1982), 693-721. 


\section{ITERABILITY AND DIFFÉRANCE}

of language in which literature finds itself anchored in, the supplementary or the pharmakonian nature of language.

For Austin, the possibility of the fulfillment of the performative function of a speech act lies within context itself ${ }^{38}$, for it governs the necessary circumstances in which a speech act is to be understood and performed according to the intention of its speaker. One cannot, for example, baptize a crocodile or pronounce a biological brother and sister as married, for the conditions and performance of these rituals already implies their individual context in which an utterance operate in order for a performance to function. Thus, in baptizing a crocodile, one fails to fulfill the condition that the one who would be baptized must be a person, or in the case of marrying a biological brother and sister, the context becomes null and void because it involves a contradiction of the system of its ceremony because the act itself is considered incestuous. Austin uses a wide variety of interesting examples, which are often humorous and at the same time demonstrative, and in these examples one can see the underlying importance of context in the manifestation of a performative. These conditions are for Derrida, prone to polysemia, whereas the variability of the recurrence or the repetition of the context is subject to circumstantial modification, and the consistency of which is always at the risk of diverging from its ideal context. A priest, for example, may find himself in a situation in which wine becomes unavailable for his congregation (for the sacrament of communion), and instead finds a keg of brandy delivered to his church by mistake. Is the priest unable to perform the sacrament of communion? Or is he allowed to modify the context so as to fulfill the performance of the sacrament despite this small contextual inconvenience? The situation could even go to the length of absurdity, in which small contextual details become replaced by larger ones, to the extent that performances would inevitably breach the domain of ethics and axiology.

But to go to the heart of the argument, Derrida situates the speech act theory in the context of writing and poses the question of the possibility of a homogenized discourse of communication and the possibility of its transference of meaning 39 . He sets the context of his essay, "Signature Event Context," on the premise that writing is able to demonstrate radical absence better than speech. ${ }^{40}$ The problem that Derrida poses against Austin is the relative claim of context in which communication is situated in, and because of the absence of

38 “. . . Speaking generally, it is always necessary that the circumstances in which the words are uttered should be in some way, or ways, appropriate, and it is very commonly necessary that either the speaker himself or other persons should also perform certain other actions, whether 'physical' or 'mental' actions or even acts of uttering further words." Austin, How To Do Things With Words, 8.

${ }^{39}$ Derrida, Limited Inc., 3.

40 Because of the intentional and unintentional probability of an absent recipient in writing, writing becomes a simpler way of conveying the problem of language as a system of communication and representation that simulates and dissimulates presence. One might as well consider Derrida's referral to writing as synonymous to speech for Derrida considers both as similar with regards to the problem of absence implied within its system. 
an author in writing, context becomes problematic in so far as the author is writing for someone who is not yet present before him:

What holds for the receiver holds also, for the same reasons, for the sender or the producer. To write is to produce a mark that will constitute a sort of machine which is productive in turn, and which my future disappearance will not, in principle, hinder its functioning, offering things and itself to be read and to be rewritten. When I say "my future disappearance," it is in order to render this proposition more immediately acceptable. I ought to be able to say my disappearance, pure and simple, my nonpresence in general, for instance the nonpresence of my intention of saying something meaningful, of my wish to communicate, from the emission or production of the mark. For a writing to be a writing it must continue to "act" and to be readable even when what is called the author of the writing no longer answers for what he has written, for what he seems to have signed . . .. ${ }^{41}$

Writing then (in Derrida's context, which involves any system of graphematics or representation) is inherently dependent on the repeatability of context, for the success of a text's performance is dependent on the unknown or undeterminable recipient's ability to synchronize intentions with its sender. The problem that the speech act theory faces, is the repeatability or the iterability of the text or utterance, for in the repetition of a statement or a performative, one faces the problem of equivocation and ambiguity, which Austin finds necessary to clarify and recontextualize. ${ }^{42}$ Explicitness, for Austin, is problematic, and one needs to express statements with clarity in order to overcome the problem of equivocation ${ }^{43}$.

The problem however, for Derrida, is that explicitness does not always lend itself to a perfect appropriation of the author or the speaker's intention, and even under the conditions of an elaborate explicitness, which can be seen inside Austin's own work, ${ }^{44}$ the intention to say something is always at the risk

${ }^{41}$ Derrida, Limited Inc., 8.

42 Austin, How to Do Things With Words, 72.

43 Austin would go as far as suggesting explicitness as a way of avoiding equivocal statements like single word statements, for example, instead of saying "suck," despite of the immediate context of the situation, one might explicitly say, "I order you to suck on this lemon after you drink a shot of tequila." Cf. ibid., 73.

44 This is perhaps why Derrida lauds Austin for the honesty and method of his writing. For example, in his attempt to distinguish performative utterances from constative utterances, Austin admits the fact that to some extent, his explication of explicitness is riddled with obscurities, and cautions his readers to take note of the complication involved in the distinction itself, perhaps even Austin himself also writes under erasure. Ibid., 67-71. 


\section{ITERABILITY AND DIFFÉRANCE}

of a possible infelicity. Convention then becomes questionable, in as far as it is always at risk, it would always involve the possibility of unintentionally creating infelicities. ${ }^{45}$ Derrida notes the discrepancies in Austin's isolation of parasitism and the possibility that it incurs infelicities:

1) that Austin, at this juncture, appears to consider solely the conventionality constituting the circumstance of the utterance [énoncé], its contextual surroundings, and not a certain conventionality intrinsic to what constitutes the speech act [locution] itself, all that might be summarized rapidly under the problematical rubric of the "arbitrary nature of the sign," which extends, aggravates, and radicalizes the difficulty. "Ritual" is not a possible occurrence [éventualite], but rather, as iterability, a structural characteristic of every mark.

2) that the value of risk or exposure to infelicity, even though, as Austin recognizes, it can affect a priori the totality of conventional acts, is not interrogated as an essential predicate or as a law. Austin does not ponder the consequences issuing from the fact that a possibility a possible risk - is always possible, and is in some sense a necessary possibility. Nor whether - once such a necessary possibility of infelicity is recognized - infelicity still constitutes an accident. What is a success when the possibility of infelicity [échec] continues to constitute its structure?46

Considering Derrida's critique of the metaphysics of presence in the history of Western ontology, this problem has already been thought of in various contexts involving mainly thinkers of Continental-European orientation. Husserl, Heidegger and Levinas, for example, point out that the subjectivity of an individual is unique to the extent that it affects the possibility of meaning, and, in turn, creates differences. The risk, for Derrida, is important to the extent that, for him, it governs the possibility of transferring meaning to an other, and in relation to his earlier critique of metaphysics, one can then say that Austin's conception of context is blatantly logocentric.

45 Austin is evidently aware of this problem to the point that he maps out the scenarios in which one would incur the possibility of infelicities, but only to the point that he is able to demonstrate the possibility of avoiding misfires and not considering them occurring even within a successful occurrence of a performative. Ibid., 18-20.

${ }^{46}$ Derrida, Limited Inc., 15. 


\section{Searle, Intentionality, and the Speech Act Theory}

Incidentally, it is in this critique of the speech act theory that one could find Derrida supporting, or at least, affirming logocentrism as a conditio sine qua non of the possibility of the transference of meaning, but only to the extent that it should be taken as a limited context that refers to the traces of singularity left at the moment of the inscription or utterance of a text. This is partially made possible by Searle's reply to Derrida's essay, which is a defense of bis interpretation of Austin from Derrida's deconstruction of the speech act theory. Searle's argument against Derrida is that the conscious state of intentionality itself determines the economy of transaction within the speaker and receiver; ${ }^{47}$ intentions then, plays an important role in determining the success of a peformative in the transaction of meaning that occurs between the speaker and the receiver. For Searle, intention is able to allay the possibility of infelicities through the explicitness of the intention of the speaker/author; he uses, for example, an imaginary hypothetical American soldier captured by Italian soldiers in the Second World War as an example of the explicitness of intention. The captured American soldier, in his attempt to avoid imprisonment, tries to speak German in order to fool the Italians, but the problem is that he only knows bits of German from a song, "Kennst du das Land wo die Zitronen blïhen?" which when translated roughly asks: "Knowest thou the land where the lemon trees bloom?" 48 For Searle, the situation in which the speech act is uttered already determines the explicitness of the intention of the soldier to fool the Italians that he was German, and even if the American soldier specifically utters in German "Ich bin ein deutscher soldat" (I am a German soldier), the effect of the intention would still reach the Italian soldiers given in this condition ${ }^{49}$. Whether the Italian soldiers understand what the American soldier is saying or not, the mere fact of speaking German already necessitates the success of the performative, ${ }^{50}$ which taken semantically, does not make any pertinent sense towards its recipient, the fact that the speaker shows his intention that he can speak German already determines the success of the speech act. The inability then, to speak German coherently, for Searle, becomes a mere circumstantial convention ${ }^{51}$ in which the Italians may overlook simply because they do not really understand what the soldier was saying.

Searle makes two distinctions in which the context of intention is set in a speech act, he states that there are two kinds of facts that govern the transference of meaning in an utterance, one of which is the brute fact and the

\footnotetext{
${ }^{47}$ Searle, Reiterating the Differences: A Reply to Derrida, 202.

48 John R. Searle, Speech Acts: An Essay in the Philosophy of Language (New York: Cambridge University Press, 1969), 44-45.

${ }^{49} \mathrm{It}$ is interesting to note that Searle has given this example under the note that certain conditions are met, such as the knowledge that the captors (Italian soldiers) know that there are German soldiers wearing American uniforms, have orders from their generals to release any German soldiers, that the captors do not know how to speak German, etc. Ibid.

${ }^{50}$ Ibid.

${ }^{51}$ Ibid., 45.
} 


\section{ITERABILITY AND DIFFÉRANCE}

other is the institutional fact. ${ }^{52}$ Brute facts are the easily and obviously acknowledged facts that are empirically validated through sense experience, ${ }^{53}$ such as "this stone is next to that stone," "Bodies attract with a force inversely proportional to the square of the distance between them and directly proportional to the product of their mass," or "I have a pain.." 54 For Searle, these facts are directly modeled after the natural sciences, ${ }^{55}$ which, later on, he considers as a redundant assertion that does not need to be stated for their existence. ${ }^{56}$ On the other hand, institutional facts, are facts that exists in so far as human convention has made it possible, ${ }^{57}$ for example, conventions such as marriage, winning a football game, or watching a documentary about America from a Kazakhstanian reporter, are facts that occur only because of its being conditioned by societal normative practices. These facts, for Searle, is what makes a speech act function in its process of conveying meaning, and it is in this regard that the homogeneity of meaning is preserved, primarily because these facts are accessible to language speakers, and thus allow the survival of an intention of an utterance or writing of the text in so far as the intention to communicate is based on the context of the speaker's (or writer's) situation. ${ }^{58}$

The problems that Derrida poses to Austin's version of the speech act theory is, for Searle, a misunderstanding of Austin's research strategy. The exclusion of parasitic from non-parasitic discourses is not a way of marginalizing particular discourses with the intention of creating ethical valuation, ${ }^{59}$ Searle maintains that the term "parasitic" in Austin's speech act theory is a way of distinguishing the standard form of discourse from its nonstandard usage (i.e. in fiction), ${ }^{60}$ which enables a distinction from the logical truth of language as evidenced by the history of human languages itself. ${ }^{61}$ Furthermore, the problems that Derrida poses towards the iterability and the repeatability of statements and utterances deviates from the original structure of language since "the speaker and hearers are masters of the sets of rules we call the rules of language, and these rules are recursive" and that "they allow for the repeated application of the same rule." 62 Searle thinks then that there is no conflict between the iterability of language and the intention ${ }^{63}$ of the

${ }^{52}$ Ibid., 50.
${ }^{5}$ Ibid.
${ }^{54}$ Ibid.
${ }^{55}$ Ibid.
56 To note, Searle finds the obviousness behind brute facts as an already given fact in

56 To note, Searle finds the obviousness behind brute facts as an already given fact in
, and it is only in special cases (i.e. teaching students physics, explaining to a child why the world, and it is only in special cases (i.e. teaching students physics, explaining to a child why the sun rises up from the east, etc.) wherein the re-assertion of these facts are to be considered logical. Ibid., 141.

${ }^{57}$ Ibid., 51.

${ }^{58}$ Searle, Reiterating the Differences: A Reply to Derrida, 200.

${ }^{59}$ Ibid., 205.

${ }^{60}$ Ibid., 207.

${ }^{61}$ Ibid.

${ }^{62}$ Ibid., 208.

${ }^{63}$ Ibid. 
speaker, precisely because it is an always already given situation for language to be, and to some extent, one might conclude that Searle is accusing Derrida of committing the fallacy of assertion, ${ }^{64}$ which for Searle is the analysis of a linguistic situation that confuses the condition of "making non-defective assertions with the conditions of the applicability of certain concepts." 65

These accusations are more or less provocative for Derrida, for in claiming that there is a "right" way of interpreting Austin, which involves the "right" way of using language, Searle is already implying that these differences are not important determinants of language, and that all speech acts follow an originary set of rules that enable absolute homogeneity with regard to the context of speech acts. This accusation results into a comprehensive polemic which takes Searle's statements word for word--as a justification that Searle has misunderstood Derrida and Austin--in as much as Searle is accusing Derrida of misunderstanding Austin.

\section{The Limits of Difference: The Eccentric Center of Logocentrism in the Iterability of the Text}

In "Limited Inc. a b c...,"66 Derrida answers Searle's accusation of misreading Austin by engaging Searle in a very explicit debate regarding the necessity of excluding parasitism in Austin's speech act theory. Derrida's rebuttal is long, sarcastic, ironic, and humorous, for it involves the reversal of Searle's position through these gestures as a way of making his points explicit. The title of the essay itself, already lends clues to its readers that this polemic is intended towards the exploration of the limitations in which context allows iterability to function. The position that Searle took in his argument against Derrida, finds notable similarities with the classical notion of representation, which is mimetic. This is not only exclusive to Searle, but also to that of Austin, which according to Derrida, finds parasitism as a dismissible and coincidental in a sense that it does not belong essentially to language ${ }^{67}$. The difference, however, between Austin and Searle is that, Austin is aware of the limitations in which his analysis of language is situated, and it is noted by Derrida that the limitations within Austin's speech act theory implies possibility as the boundary in which Austin's axioms operate. Searle, on the other hand, is adamant to consider parasitism as a probable means of explication, and thus considers Derrida's criticism to be missing out the explicit details of Austin's method.

To put it succinctly, Derrida's polemic against Searle is based on his notion of différance, as the possibility and limitation of possibility in which context is constituted in communication. Derrida maintains that iterability carries with it a sense of absence ${ }^{68}$ which was gravely misunderstood by Searle as

\footnotetext{
${ }^{64}$ Searle, Speech Acts, 141.

65 Ibid., 144.

${ }^{66}$ Cf. Jacques Derrida, "Limited Inc. a b c. . .," in Limited Inc.

${ }^{67}$ Derrida, "Signature Event Context," in Ibid., 17.

${ }^{68}$ Derrida, Limited Inc., 47.
} 


\section{ITERABILITY AND DIFFÉRANCE}

merely the "absence of an author" in a discourse. In speaking of absence, Derrida intends to state that the intention of the author itself is tainted with imperfection as the entirety of the singularity of the inscription or the utterance of a performative is in itself lost in such moment, thus, radical absence as conceived by Derrida implies the possibility of mis:

. . The relation of "mis" (mis-understanding, misinterpreting, for example) to that which is not "mis-," is not at all that normality, of the "standard." All that I recall is that this structural possibility must be taken into account when describing so-called ideal normality, or socalled just comprehension or interpretation, and that this possibility can be neither excluded nor opposed. An entirely different logic is called for. ${ }^{69}$

For those who are in search of a logic, or a telos behind the intention of deconstruction to deconstruct, one might find this statement exacting, if not limiting. The critique of the metaphysics of presence that Derrida conducts through his deconstructive readings bases its criticism on this lack of acknowledgement for the structural possibility of interruption and disruption, and thus it is precisely in this line of thought that deconstruction could sometimes be considered skeptical and at times nibilistic for it effaces the very foundation of the claim of a system (i.e. Saussure's signifier/signified, LeviStrauss' and Rousseau's notion of purity, Levinas' notion of infinity, Heidegger's distinction between man and animal, etc.) to have an ideally working set of distinctions between its inside and its outside, between its purity and its impurity, itself and its Other, etc. The problem of linguistic systems that claims the possibility of an absolute repetition of a statement or utterance is that they usually fail to acknowledge that what is being repeated, mimed, copied, is not the same as its original.

This, however, does not imply that it is impossible to communicate meaning, ${ }^{70}$ for what is implied in the possibility of mis is that representation itself is imperfect, and mis as a constant standing possibility that plays itself within communication, implies a possibility and not an absolute condition of mis-

${ }^{69}$ Ibid., 157.

${ }^{70}$ Derrida, despite the speculation of his critics, does not deny the possibility of meaning in the texts, he merely points out how the text itself dissimulates its claims of presence, precisely because it refers to something that has passed away, or had become inaccessible in its entirety. One may find this affirmation in his notion of the trace, wherein the residues of an original presence, is still capable, to some degree, of reconstructing the lost presence. Hence, Derrida's discourse is always seemingly unconventional: ". . . deconstruction tries to show that the question of reference is much more complex and problematic than traditional theories supposed ... But to distance oneself thus from the habitual structure of reference, to challenge or complicate our common assumptions about it, does not amount to saying that there is nothing beyond language." Jacques Derrida, "Deconstruction and the Other", in Dialogues with Contemporary Continental Thinkers, ed. by R. Kearney (Manchester: Manchester University Press, 1984), 124. 
communication. The text or utterance itself is, for Derrida, re-traceable, but retracing it, however, brings the discourse back to the inevitability of turning back to différance. The text itself is a scattered remnant of its originary inception; hence, one will agree with Derrida that the meaning behind the text is essentially disseminated, and the only thing that keeps its meaning or gives the meaning behind the text the possibility of congruency with its interlocutor is its syntax. Difference itself is a ontological concept that represents an actual occurrence within the economy of signs and representations, it is for him, not a nibilistic process of suspending meaning, but a creative play of differences that occurs as a consequence of the effort to hold back presence in its evanescent elusion. ${ }^{71}$ The mark that is left by différance is always already a mark that tells the difference, it is at the same time simulating and dissimulating its claims of presence in the gesture of signification:

The iterability [repeatability] of the mark does not leave any of the philosophical oppositions which govern the idealizing abstraction (for instance, serious/non-serious, literal/metaphorical or sarcastic, ordinary/parasitical, strict/non-strict, etc.). Iterability blurs a priori the dividing-line that passes between these opposed terms, "corrupting" if you like, contaminating it parasitically, qua limit. What is re-markable about the mark includes the margin within the mark. The line delineating the margin can therefore never be determined rigorously, it is never pure and simple. The mark is re-markable in that it "is" also its margin. ${ }^{72}$

In opposition to Searle's position, the iterability of the mark, utterance, or the text is already dissimulated once it is communicated and with much sarcasm, Derrida states that it might have been possible that he had misinterpreted Austin in as much as Searle has misinterpreted Austin. ${ }^{73}$ Moreover, Derrida pointed out that one of the major blunders in Searle's reading of the Signature Event Context is the fact that three important points were left out in Searle's analysis, mainly: (1) Signature, (2) Event, and (3) Context. ${ }^{74}$

What is striking about this omission however is that Searle misses this unified explanation of Derrida's elusive notion of differrance, and it is in this three

71 "For us, différance remains a metaphysical name, and all the names that it receives in our language are still, as names, metaphysical. And this is particularly the case when these names state the determination of differance as the difference between presence and the resent, and above all, and is already the case when they state the determination of differance as the difference of Being and beings." Derrida, Margins of Philosohpy, 26.

72 Derrida, Limited Inc., 70 [my own interpolation].

${ }^{73}$ Ibid., 37.

${ }^{74}$ Ironically, Searle seems to have missed the entire point of the essay, the very title that is. Ibid., 46. 


\section{ITERABILITY AND DIFFÉRANCE}

particular points that I find Derrida explicitly elaborating on these three points and its importance in the development of the ontology of différance. Starting with signatures, Derrida opines that iteration, mimesis, and repetition should be taken as constitutive of inscription. The signature is important for both Austin and Derrida ${ }^{75}$ in so far as it establishes the site of the construction of an utterance or writing. The signature answers the question "who is it that speaks, or has written before me?" It allows the interlocutor to understand (in a limited fashion) the absence that the author has left for others to see, and in this case Derrida agrees with Austin, precisely because Austin admits to some extent that communication involves a radical form of absence. The possibility of a rapprochement between Derrida and Austin should be articulated. Austin explains this possibility of a radical absence in an utterance:

The 'I' who is doing the action does thus come essentially into the picture. An advantage of the original first person singular present indicative active form - or likewise of the second and third and impersonal passive forms with signature appended - is that this implicit feature of the speech-situation is made explicit. More-over, the verbs which seem, on grounds of vocabulary, to be specially performative verbs serve the special purpose of making explicit (which is not the same as stating or describing) what precise action it is that is being performed by the issuing of the utterance: other words which seem to have a special performative function (and indeed have it), such as 'guilty,' 'off-side,' \&c, do so because, in so far as and when they are linked in 'origin' with these special explicit performative verbs like 'promise,' 'pronounce,' 'find,' \&c. . . Thus what we should feel tempted to say is that any utterance which is in fact a performative should be reducible, or expandible, or analyzable into a form, or reproducible in a form, with a verb in the first person singular present indicative active (grammatical). ${ }^{76}$

To note, Derrida does not only find the mention of the singular present indicative active form to be a precise description of the tenses used in an utterance, it also serves, for him, as an explicit description of the activity occurring at the instance of utterance and writing itself:

By definition, a written signature implies the actual or empirical nonpresence of the signifier. But, it will be claimed, the signature also marks and retains his havingbeen present in a past now or present [maintenant] which

\footnotetext{
${ }^{75}$ Ibid., 19.

${ }^{76}$ Austin, How to Do Things With Words, 61-62.
} 
will remain a future now or present [maintenant], thus in a general maintenant, in the transcendental form of presentness [maintainance]. That general maintenance is in some way inscribed, pinpointed in the always evident and singular present punctuality of the form of the signature. Such is the enigmatic originality of every paraph. In order for the tethering to the source to occur, what must be retained is the absolute singularity of a signature-event, and a signature-form: the pure reproducibility of a pure event. ${ }^{77}$

Signatures in their iteration imply singularity, which, in turn, affirms the condition that it is what it is and at the same time it is what it is not. In inscribing a signature, one affirms the condition that it is done in the present with the anticipation that the presence in its inscription will no longer be present. In other words, signatures express that the absolute singularity who has been there in its inscription, is no longer present, and the trace that is there for someone or anyone who takes interest in the presence of an absent utterer or writer. As Austin would note, inscribing a signature or the usage of present indicative active form of the pronoun "I" transforms an otherwise implicit utterance into an explicit one because it leaves traces of its context, inscribed within the actual occurrence of an event. Thus in uttering the statement "That bull is dangerous!" the equivalent indication that an author or an utterer would leave in this singular instance of warning an other similarly appears like so:

\section{This bull is dangerous.}

$$
\text { (Signed) John Jones. }{ }^{78}
$$

The expression of singularity that Derrida's essay, "Signature Event Context," is based entirely on temporality, whereas instances are differentiated from another instance through the difference of its circumstance of its occurrence. These differences, however, are not mutually excluded in totality. Signatures, according to Derrida, demonstrate difference and ipseity in their iteration, the purity of their repeatability is always questionable, yet in the repetition of its inscription, the signatures itself retains its functions despite the differences that it incurs from the circumstance of its inscription. ${ }^{79}$ The assertion of this occurrence of differance is again, not a nihilistic approach of doing ontology through aporia, ${ }^{80}$ rather it is a creative process in which

77 Derrida, Limited Inc., 20.

78 Austin, How to Do Things With Words, 62.

${ }^{79}$ Derrida, Limited Inc., 20.

80 This is to take into account the classical sense of aporia as an irresolvable conflict between two contradicting statements (i.e. All Cretans are Liars, and I am a Cretan). Derrida develops elsewhere a positive concept of aporia that considers it as a logic of plurality rather than that of contradiction. Cf. Jacques Derrida, Aporias, trans. by Thomas Dutoit, (California: Stanford University Press, 1993), 20-21. 


\section{ITERABILITY AND DIFFÉRANCE}

transformation takes place in ontology. Differance does not mark the end of communication, rather, for Derrida, it opens new possibilities that are latent behind the text itself, and this is what he considers as an epoch of writing:

As writing, communication, if we retain that word, is not the means of transference of meaning, the exchange of intentions and meanings, discourse and the "communication of consciousnesses." We are witnessing not an end of writing that would restore, in accord with McLuhan's ideological representation, a transparency or an immediacy to social relations; but rather the increasingly powerful historical expansion of a general writing, of which the system of speech and consciousness, meaning, presence, truth, etc., would be only an effect, and should be analyzed as such. It is the exposure of this effect that I have called elsewhere logocentrism. ${ }^{81}$

This reference to logocentrism, however, is a clarification of his earlier reference to onto-theology ${ }^{82}$, logocentrism in this context refers to a structure of reference that changes or sways within time. The discussions made earlier prove the point that logocentrism operates within the context of differance; this is made apparent by Derrida's position on iteration, particularly with signatures. What is made explicit however, in Derrida's debate with Searle, is that the context or the circumstance in which the event of a speech act occurs, is always differing and yet at the same time, subscribing within the already given structure of language. One should not perceive or think of logocentrism as an inherent problem of meaning, for in its operation, logocentrism immediately effaces itself through its grafting ${ }^{83}$ with another context, and through this the center in which the text refers itself to, trembles and in turn becomes an eccentric center that become a gateway for a future that has yet to come.

\section{The Possibility of Parasitical Symbiosis: Moving Beyond the Classical Concept of Writing}

To go back to Searle's argument against Derrida, one must simply recall Derrida's position against the classical concept of writing as a repetition of speech or even that of presence, and within this context one would be able to see that for Derrida, parasitism is symbiotic. In what sense then does it become symbiotic and parasitic at the same time? Since writing already implies the

\footnotetext{
${ }^{81}$ Ibid.

${ }^{82}$ Derrida, Of Grammatology, 12.

83 This term connotes the transformation of the text as it becomes transplanted towards various contexts. Derrida discusses this elaborately on both "Signature Event Context" and "Limited Inc. a b c...." See Limited Inc., 12 and 80-82.
} 
radical absence of a source, writing has been deemed evil, if not detrimental, towards the appropriation of presence. To recall, however, the arguments that Derrida raised against this accusation, one can see that speech itself is a kind of writing. ${ }^{84}$ And to this extent, both are representations of representations, which, in other words, are parasites with regard to their consistent reference to presence. Searle's accusation of Derrida might be deemed parasitical in this sense:

I believe he [Derrida] has misunderstood Austin in several crucial ways and the internal weakness in his argument are closely tied to these misunderstandings. In this section therefore I will very briefly summarize his critique and then simply list the major misunderstandings and mistakes. ${ }^{85}$

To Derrida's ire, this statement demonstrates Searle's misunderstanding of Derrida himself (perhaps due to his own ire) and, to note, Derrida undertakes this so-called "misunderstanding" as a continuation of Austin's recognition of the limitation within his analysis of the speech act theory. ${ }^{86}$ The point here is that, in reading Derrida, Searle has already demonstrated the fact that context and intention can never be the perfect basis of establishing the success of uttering a performative, which, in Derrida, is not even possible. Context itself, just like the signature, could never be repeated perfectly as it was conceived to be.

Words itself offer a context, a limited one, that is, wherein the arrangement and syntax of texts provide a partial, if not, a total glimpse of the author's intention. In this way, one must conceive of writing, on one hand, as symbiotic to the intention of the author in as much as it enables its interlocutors to understand the text even in the radical absence (or death) of the author, and, on the other hand, can be deemed as parasitical in so far as it is unable to fully express the intention of the author, ${ }^{87}$ which in turn is to be considered as a relation of parasitism. Parasitism itself, implies internality, ${ }^{88}$ and to correct Searle (and perhaps even Austin), Derrida proposes a different way of looking at the phenomena of iterability or mimesis with regards to Searle's version of context, a system of mimesis that acknowledges its own repetition of the logos as a different copy. ${ }^{89}$ Derrida corrects the traditional notion of the

84 Like writing, speech also involves the radical absence of presence, since the immediacy of meaning conveyed by speech is also necessitated by a gap between the "I" and the "Other" in their respective and irreducible singularities. Speech then is a representation of a representation.

${ }^{85}$ Searle, "Reply to Derrida: Reiterating the Differences," 203.

${ }^{86}$ Derrida, Limited Inc., 86-87.

87 This misfires, as Austin would call it, is for Derrida is a problem of the conscious and unconscious within the intention of the utterer. Derrida alludes to psychoanalysis, as a rebuttal towards Searle's statement that "intentions must be conscious." Ibid., 73-75.

${ }^{88}$ Ibid., 96-98.

${ }^{89}$ Ibid., 90. 


\section{ITERABILITY AND DIFFÉRANCE}

logic of mimesis as differance. To give more emphasis to this point, he claims that "there is no pure performative" ", precisely because the repetition of the utterance within the consciousness of the speaker is mediated by the consciousness of its recipient, and even if (to recall Searle) there is a system or an overarching grand-recit of some kind that governs the standards of communication (i.e. grammar), this system is still prone to the possibility of parasitism primarily because of the differences in the unique plenitude of consciousnesses that would subscribe (and violate) to this constant context. To write in line with Derrida's gesture, I find that the opposition between parasitic and non-parasitic discourses is clarified, if a positive term is introduced within this paradigm. Thus, in place of the "positive" opposite, I would prefer to use symbiosis as the "other" of parasitism. The choice of this word comes with the intention of elevating this discourse into the possibility of integrating parasitism as a constant element of the speech act theory, rather than considering parasitism as an isolated or an accidental occurrence in an utterance.

One should then take the following questions in mind: Is there a way out of logocentrism? Is it possible to have a concurrence of meaning despite the deviations of parasitism? If not, where then do signs refer to if there is no fixed meaning? These questions would help one in understanding the entire proceeding of Derrida's dealings with speech act theory; for in the course of his debate with Searle, différance becomes more or less obvious in their varying positions. To conclude, I consider both Derrida and Searle to be logocentric, not that they had any choice to be otherwise, but only because the so-called "debate" or "confrontation" would not have been possible if neither of the two had focused their energies on Austin. The logos would be there, always be there, but it would be only in preparation for those to come. And in the coming of the others this logos becomes other than itself. The search for an originary logos may perhaps end here and instead usher in a different understanding of what logocentrism is. And in this fleeting moment wherein the center holds at the inscription of these words, the I would insist that differance and logocentrism be put together in an ouroboric activity of referring and differing.

$$
\text { College of Accountancy, University of Santo Tomas, Philippines }
$$

\section{References}

Austin, J.L., How To Do Things With Words, ed. by J.O. Urmson and Marina Sbisà (London: Oxford University Press, 1975).

Derrida, Jacques., Aporias, trans. by Thomas Dutoit (California: Stanford University Press, 1993),

"Deconstruction and the Other," in Dialogues with Conteporary

Continental Thinkers, ed. by R. Kearney (Manchester: Manchester University Press, 1984).

${ }^{90}$ Ibid. 
Dissemination, trans. by B. Johnson (Chicago: University of Chicago Press, 1981).

Limited Inc., trans. by S. Weber and J. Mehlman (Evanston, Illinois: Northwestern University Press, 1988).

Margins of Philosophy, trans. by A. Bass (Chicago: University of Chicago Press, 1982).

Fish, Stanley E., With the Compliments of the Author: Reflections on Austin and Derrida, Jacques Derrida, Vol. 2, ed. by Christopher Norris and David Roden (London, SAGE Publications, Ltd., 2003), 205-233.

Halion, Kevin., "Deconstruction and Speech Act Theory: A Defense of the Distinction Between Normal and Parasitical Speech Acts," in $<$ http://www.kkhec.ac.ir/Linguistics\%20articles\%20index/Deconstru ction $\% 20$ and $\% 20$ Speech $\% 20$ Act $\% 20$ Theory $\% 20$ -

\%20Austin,\%20Derrida,\%20Sear.htm>,Accessed on December 18, 2009.

Searle, John R., "Reiterating the Differences: A Reply to Derrida," in Glyph 1 (1997).

Speech Acts: An Essay in the Philosopby of Language (New York: Cambridge University Press, 1969). 